\section{Regards sur l'économie allemande}

Bulletin économique du CIRAC

$118-119 \mid 2015$

Varia

\title{
Histoire des idées
}

HORN Karen (Hrsg.), Verlockungen zur Unfreiheit. Eine kritische Bibliothek von 99 Werken der Geistesgeschichte

Isabelle Bourgeois

\section{(2) OpenEdition}

1 Journals

Édition électronique

URL : http://journals.openedition.org/rea/4927

DOI : $10.4000 /$ rea. 4927

ISSN : 1965-0787

Éditeur

CIRAC

\section{Édition imprimée}

Date de publication : 31 décembre 2015

Pagination : 46

ISSN : 1156-8992

\section{Référence électronique}

Isabelle Bourgeois, «Histoire des idées », Regards sur l'économie allemande [En ligne], 118-119|

décembre 2015, mis en ligne le 31 décembre 2015, consulté le 25 septembre 2020. URL : http:// journals.openedition.org/rea/4927 ; DOI : https://doi.org/10.4000/rea.4927

Ce document a été généré automatiquement le 25 septembre 2020.

(c) CIRAC 


\section{Histoire des idées}

HORN Karen (Hrsg.), Verlockungen zur Unfreiheit. Eine kritische Bibliothek von 99 Werken der Geistesgeschichte

\section{Isabelle Bourgeois}

\section{RÉFÉRENCE}

HORN Karen (Hrsg.), Verlockungen zur Unfreiheit. Eine kritische Bibliothek von 99 Werken der Geistesgeschichte, Verlag Neue Zürcher Zeitung, Zurich/Frankfurter Allgemeine Buch, Francfort-sur-le-Main, 2015, 416 p.

1 Cet ouvrage collectif est publié par un cercle d'auteurs proches de la société Friedrich A. von Hayek, un think tank libéral constitué en 1998 à Lahr, près de Fribourg-enBrisgau par des chercheurs, des entrepreneurs et des journalistes dans le but de promouvoir la pensée de ce philosophe autrichien, principalement son idée de société libre, exposée dans La Constitution de la Liberté (1960). Le présent ouvrage fait suite à un premier, paru en 2008 et intitulé Die Idee der Freiheit (L'idée de la liberté), recensant 111 textes ou extraits sur ce thème - et il en prend le contre-pied. «Les tentations de la nonliberté " (son titre) rassemble 99 textes ou extraits décrivant ou analysant toutes ces valeurs qui sont susceptibles de se révéler liberticides ou tendent tout du moins à sévèrement contrecarrer la valeur fondamentale « liberté » : égalité, justice (sociale ou autre), raison, puissance nationale, respect des traditions ou encore protection de la Création. La liberté, au fond, est le principe fondateur de la tolérance sans laquelle aucun vivre ensemble n'est possible. Son absence mène à l'autoritarisme, voire au totalitarisme. C'est là une très riche compilation qui, dans sa simplicité même - elle se contente de mettre à disposition des textes-clés, des auteurs choisis parmi les grands noms de la pensée -, donne à réfléchir au lecteur et enrichit sa pensée. 